\title{
Implementasi Aplikasi Pixton Sebagai Upaya Meningkatan Keterampilan Pembuatan Bahan Ajar Digital Dalam Bentuk Komik Untuk Mahasiswa Calon Guru Sekolah Dasar
}

Dede Trie Kurniawan ${ }^{1}$, Nailah Tresnawati ${ }^{2}$, Sri Maryanti ${ }^{3}$

1)Program Studi PGSD Universitas Swadaya Gunung Jati Cirebon; dhe3kurniawan@gmail.com

2)Program Studi PGSD Universitas Swadaya Gunung Jati Cirebon;

3)Program Studi Pendidikan Biologi FTK UIN Sunan Gunung Djati Bandung;

Abstrak. Komik edukasi dapat menyampaikan materi pembelajaran dengan menarik, sehingga cocok digunakan untuk media pembelajaran. Penelitian ini bertujuan untuk mengembangkan metode perkuliahan mahasiswa calon guru sekolah dasar dalam memanfaatkan teknologi informasi dan komunikasi dalam pembuatan media komik pembelajaran pendidikan lingkungan hidup untuk siswa sekolah dasar. Metode yang dipakai untuk mencapai tujuan yaitu melalui penelitian pengembangan (Development Research) dengan model ADDIE (Analisis, Design, Development, Implementation dan Evaluation) yang diarahkan untuk mengembangkan komik pembelajaran pendidikan lingkungan hidup (PLH) berbasis TIK dengan aplikasi PIXTON. Penelitian ini berupaya untuk mengembangkan metode perkuliahan yang dapat memberikan keteramipilan pembuatan bahan ajar digital dalam bentuk komik untuk mahasiswa calon guru sekolah dasar di salah satu perguruan tinggi swasta kota Cirebon. Hasil Penelitian menunjukan mahasiwa calon guru sekolah dasar mampu merancang dan membuat komik dengan aplikasi pixton dalam mengembangkan materi pembelajaran sekolah dasar untuk mata pelajaran pendidikan lingkungan hidup.

Kata Kunci. Komik, Teknologi Digital, Pedidikan Lingkungan, Sekolah Dasar

Abstract. Educational comics can convey learning material interestingly, making it suitable for use in learning media. This study aims to develop lecture methods for prospective elementary school teacher students in utilizing information and communication technology in the making of comic media for environmental education learning for elementary school students. The method used to achieve the goal is through development research (Development Research) with the ADDIE model (Analysis, Design, Development, Implementation and Evaluation) which is

Caruban: Jurnal Ilmiah Pendidikan Dasar 2(2), 71-83, Juli 2019

p-ISSN 2615-1391, e-ISSN 2620-3219 @Prodi PGSD Universitas Swadaya Gunung Jati 
directed to develop ICT-based environmental education learning comics (PLH) with the application of PIXTON. This study seeks to develop lecture methods that can provide the ability to manufacture digital teaching materials in the form of comics for prospective elementary school teacher students in one of the private universities in Cirebon. The results showed that prospective elementary school teacher students were able to design and create comics with the Pixton application in developing elementary school learning materials for environmental education subjects.

Keywords: Comics, Digital Technology, Environmental Education, Elementary Schools

\section{Pendahuluan}

Komik edukasi adalah salah satu bentuk jenis komik yang kini sedang berkembang dalam popularitas. Salah satu keunikan jenis komik ini adalah selain memiliki konten cerita dan narasi komik pada umumnya, komik edukasi juga memiliki konten edukasi dan informasi terkait subjek pelajaran yang disampaikannya, sehingga cocok digunakan untuk media pembelajaran. Komik edukasi mencakup berbagai macam subjek mulai dari sains, sejarah, cara menghemat uang, hingga cara berpakaian. Jenis komik ini di Korea Selatan juga telah mendapat pengakuan sebagai alat pembelajaran di sekolah (The Korea Times, 2010), dan jenis komik tersebut juga mulai ramai digunakan sebagai media pembelajaran di Amerika (Cary, 2004: 52).

Komik edukasi dapat menyampaikan materi pembelajaran dengan menarik, sehingga cocok digunakan untuk media pembelajaran. Elemen visual, materi pelajaran, dan penceritaan komik dapat dikemas dalam bentuk yang menarik dan edukatif, sehingga dapat dengan mudah dimengerti oleh anakanak yang membacanya, serta menghibur. Komik adalah media populer yang digemari anak-anak dan dapat menyampaikan informasi secara jelas menggunakan teks dan gambar.

Salah satu cara untuk memberikan pendidikan lingkungan pada siswa Sekolah Dasar adalah dengan menggunakan komik edukasi. Komik edukasi adalah cerita yang bertekanan pada gerak dan tindakan yang ditampilkan lewat urutan gambar yang dibuat secara khas dengan panduan kata-kata. Menurut Yudhi Munadi (2008:100) mendefenisikan komik juga dapat dijadikan media pembelajaran. Gambar dalam komik biasanya berbentuk atau berkarakter

Caruban: Jurnal Ilmiah Pendidikan Dasar 2(2), 71-83, Juli 2019

p-ISSN 2615-1391, e-ISSN 2620-3219 @Prodi PGSD Universitas Swadaya Gunung Jati 
gambar kartun. Dengan gambar yang menarik, bahasa yang sederhana, mudah dipahami dan mudah dimengerti siswa. Komik edukasi akan menjadi media yang tepat untuk mengajarkan bagaimana cara melestarikan dan menjaga keleastarian lingkungan hidup.

Komik edukasi merupakan salah satu bentuk media pembelajaran yang dapat menentukan keberhasilan suatu pembelajaran. Untuk itu mahasiswa calon guru sekolah dasar perlu memahami dan menguasai bagaimana tahapan, proses dan capaian keterampilan pembuatan komik dengan memanfaatkan aplikasi teknologi digital. Selama ini belum adanya modul perkuliahan khusus yang membahas mengenai pelatihan pembuatan komik dengan teknlogi digital untuk mahassiwa calon guru sekolah dasar. Melalui aplikasi ini walaupun mahasiswa tidak memiliki keterampilan gambar yang baik, mahasiswa tetap bisa membuat komik dengan bantuan aplikasi ini. Dengan latar belakang inilah, peneliti perlu melakukan penelitian pengembangan untuk membuat sebuah model perkuliahan yang membekalkan kemampuan mennggunakan teknologi digital dalam pembelajaran yang salah satu produknya adalah pembuatan komik. Tidak hanya mengembangkan sebuah model perkuliahan, penelitian ini juga berupaya mengembangkan instrumen untuk menilai produk dan kelayakan komik edukasi yang dibuat melalui aplikasi teknologi digital Pixton. Penelitian ini bertujuan untuk mengembangkan metode perkuliahan mahasiswa calon guru sekolah dasar dalam memanfaatkan teknologi digital dalam pembuatan media komik pembelajaran dengan konten pendidikan lingkungan hidup untuk siswa sekolah dasar.

\section{Metode}

Penelitian ini merupakan penelitian pengembangan (Reserarch and development) dengan menggunakan model pengembangan Hanafin dan Peck. Model pengembangan ini terdiri dari beberapa fase yaitu fase analisis kebutuhan (need assesment), fase peracangan (design) dan fase pengembangan dan implementasi (development and implementation) (Hanafain \& Peck, 1988). Dalam model ini, penilaian dan revisi perlu dijalankan dalam setiap fase. Model Pengembangan Hanafin dan Peck merupakan model yang lebih beroreientasi produk sehingga sesuai digunakan untuk mengembangnkan model 
perkuliahan dan instumen penilaian bahan ajar berbentuk komik dengan aplikasi pixton kreasi mahasiswa calon guru sekolah dasar.

Penelitian ini akan dilaksanakan di LPTK swasta negeri kota cirebon yang menyelenggarakan program studi pendidikan guru sekolah dasar. Subjek penelitian adalah mahasiswa calon guru sekolah dasar semester III program S1 yang sedang mengikuti perkuliahan pengembangan materi ajar sekolah dasar. Populasi penelitian adalah seluruh mahasiswa calon guru sekolah dasar. Sampel dipilih dengan teknik purposive sampling.

Kegiatan pengembangan instrumen penilaian bahan ajar digital untuk mahasiswa calon guru biologi akan dilaksanakan dalam beberapa tahapan yang dijelaskan pada gambar 6 berikut ini.

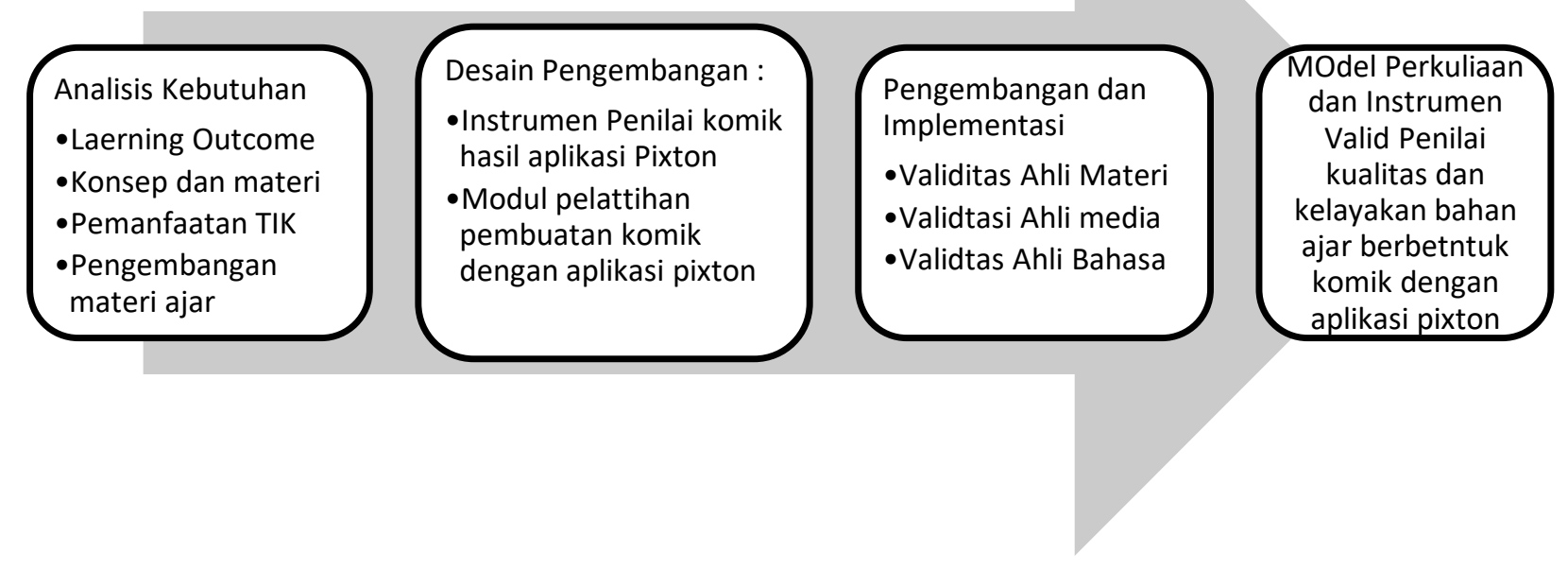

Gambar 1. Tahapan Pelaksanaan Kegiatan 


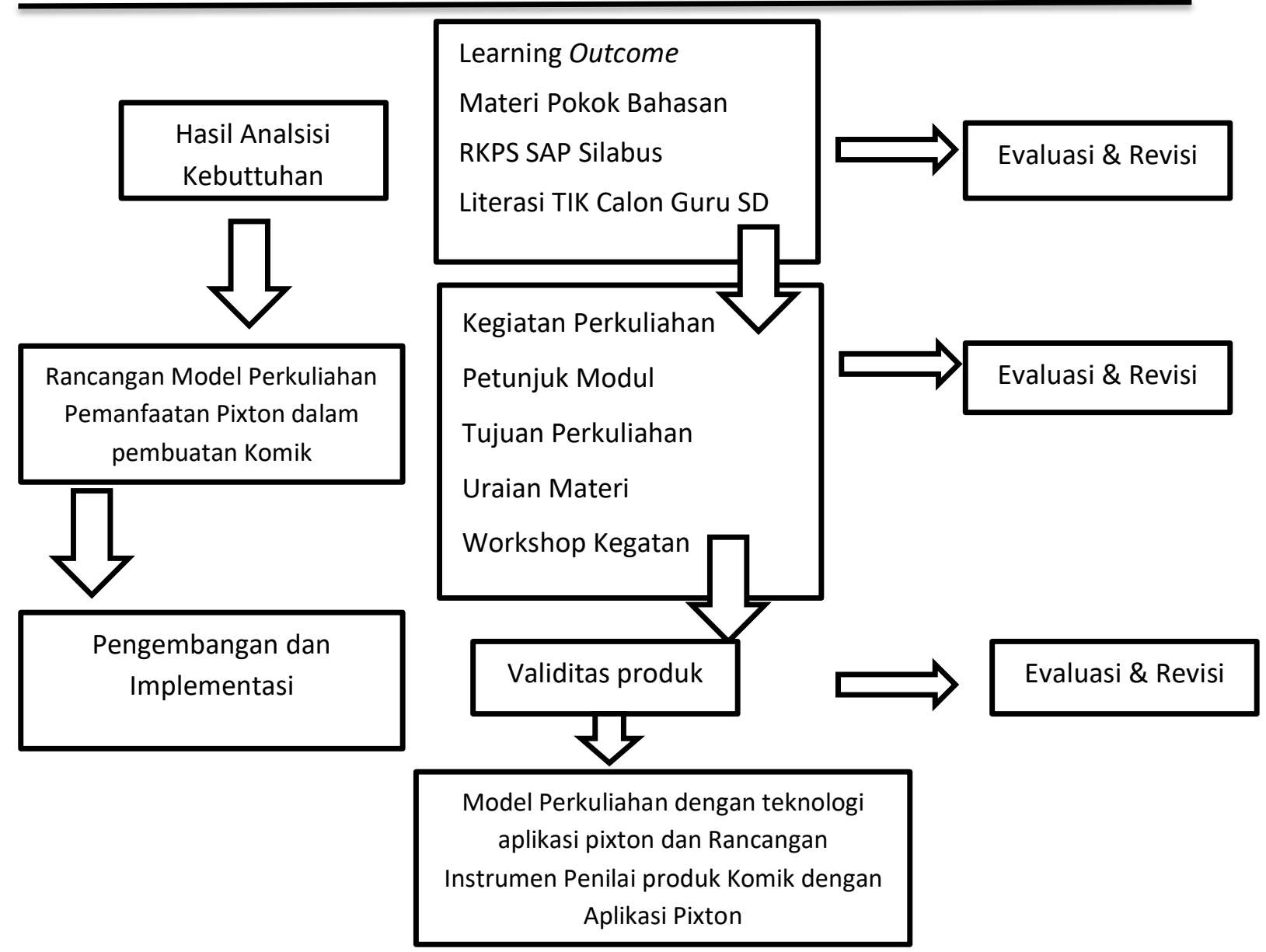

Gambar 2. Kerangka Penelitian

Dalam Pengembangan Instrumen ini prosedur pengembangan di paparkan sebagai berikut :

\section{Analisis Kebutuhan ( need assesment )}

Analisis kebutuhan dilakukan dengan mengidentifikasi kebutuhan kebutuhan yang diperlukan dalam menegmbangkan instrumen penilaian produk bahan ajar digital ini. Pada tahap ini peneliti melakukan kajian terhadap kebutuhan yang diperlukan dalam pengembangan instrumen yaitu meliputi analisis terhadap kurikulum, rencana kegiatan perkuliahan semester (RKPS), materi, mahasiswa, tugas serta merumuskan tujuan ataupun hasil yang di harapkan dalam pengembangan model perkuliahan dan instrmen penilaian bahan ajar komik dengan aplikasi pixton. Setelah semua keperluan 
diidentaifikasi Hanafin \& Peck (1988) mendekankan menjalankan penilaian terhadap hasil tersebut sebelum meneruskan ke fase berikutnya.

\section{Perancangan ( design )}

Pada fase ini informasi dari fase analisis dipindahkan kedalam bentuk dokumen yang akan menjadi tujuan pembuatan model perkuliahan dan instrumen penilaian produk ini. Fase desain bertujuan untuk mengidentifikasi dan mendokumentasikan kaidah yang paling baik untuk mencapai tujuan pengembangan model perkuliahan dan instrumen penialian produk tersebut. Pada tahap ini menyusun dokemen berupa komponen pengembangan model perkuliahan dan penilaian dan rubrik kriteria penilaiannya. Tahap desain ini bisa digambarkan dalam bentuk story board atau flow chart yang akan dikembangkan dalam model perkuliahan dan instrumen penilaian bahan ajar komik dengan aplikasi pixton. Model perkuliahan dan Instrumen penilaian produk bahan ajar komik dengan aplikasi pixton yang telah rampung di evaluasi oleh ahli evaluasi pembelajaran Sekolah dasar, ahli materi biologi lingkungan hidup dan ahli multimedia pembelajaran. Hasil kajian para ahli dijadikan masukan untuk menyempurnakan rancangan yang telah dibuat. Selanjutnya peneliti mengembangkan model perkuliahan dan instrumen penilaian bahan ajar komik dengan aplikasi pixton sehingga didapat model perkuliahan dan instrumen yang valid internal maupun eksternal.

\section{Pengembangan dan implementasi ( develpoment and implementation )}

Aktifitas yang dilakukan pada fase ini diantaranya pengujian dan penilaian. Pada tahapan ini dibatasi pada penialian formatif yaitu uji validitas instrumen penilaian produk bahan ajar komik dengan aplikasi pixton yang dilakukan oleh validator dari ahli evalasi pendidikan, ahli pendidikan biologi lingkungan hidup dan ahli multimedia pembelajaran. Instrumen penilaian bahan ajar komik dengan aplikasi pixton yang telah divalidasi kemudian direvisi dan disempurnakan.

Data hasil validasi di analisis dengan teknik analisis presentase. Adapun rumus yang digunakan untuk menghitung hasil angket dari validator adalah sebagai berikut: 
$P=\frac{\sum x}{\sum x i} x 100 \%$

Keterangan :

$\mathrm{P} \quad$ : Presentase

$\sum \mathrm{x} \quad$ : Jumlah keseluruhan jawaban responden

$\sum x i \quad$ Jum;ah keseluruhan nilai ideal dalam 1 item

(Arikunto, 2008 :216)

Pedoman pengambilan keputusan dari analisis data menggunakan skala kualifikasi untuk menentukan kesimpulan. Kriteria kelayakan hasil validasi disajikan dalam tabel 1 berikut ini.

Tabel 1. Kriteria kelayakan dari tiap item

\begin{tabular}{ll}
\hline Tingkat Presentase & Kriteria \\
\hline $25-39$ & Tidak Layak \\
$40-54$ & Kurang Layak \\
$55-69$ & Cukup Layak \\
$70-84$ & Layak \\
$85-100$ & Sangat layak \\
\hline
\end{tabular}

(Slavin, $1992: 78$ )

\section{Hasil Penelitian dan Pembahasan}

\section{Komik Sebagai Media Pembelajaran}

Anak-anak tentu tidak asing dengan buku komik. Komik menyajikan cerita bergambar yang mampu menarik anak-anak untuk membacanya. Namun komik yang beredar di pasaran tidak semuanya mengandung nilai edukatif. Komik menjadi suatu bentuk bacaan dimana anak mau membacanya tanpa harus dibujuk. Melihat popularitas komik yang banyak disukai anak-anak bahkan sampai dewasa, maka komik memiliki potensi yang besar digunakan sebagai media pendidikan.

Daya tarik komik terdapat pada ilustrasi gambar yang menarik dengan teks yang relatif singkat. Pemakaian komik yang luas dengan ilustrasi berwarna, alur cerita yang ringkas dengan perwatakan tokohnya yang realistis menarik siswa dari berbagai usia utuk membacanya. Dengan bimbingan guru, komik dapat mejadi media meningkatkan minat baca peserta didik. Pada mulanya komik ditujukan untuk membuat gambar-gambar yang menceritakan 
secara semiotic (simbolis) maupun secara hermeneutics (tafsiran) tentang halhal yang lucu (M.S Gumelar, 2011: 2). Kartun sebagai salah satu bentuk komunikasi grafis adalah suatu bentuk gambar interpretatif yang menggunakan simbol-simbol untuk menyampaikan suatu pesan secara cepat dan ringkas atau sesuatu sikap terhadap orang, situasi atau kejadian-kejadian tertentu. Kartun tanpa digambar detail dengan menggunakan simbol-simbol serta karakter yang mudah dikenal dan dimengerti dengan cepat. Kalau makna kartun mengena, pesan yang besar bisa disajikan secara ringkas dan kesannya akan tahan lama di ingatan. Kemampuannya besar sekali untuk mempengaruhi sikap maupun tingkah laku (Arief S. Sadiman dkk, 2011: 45).

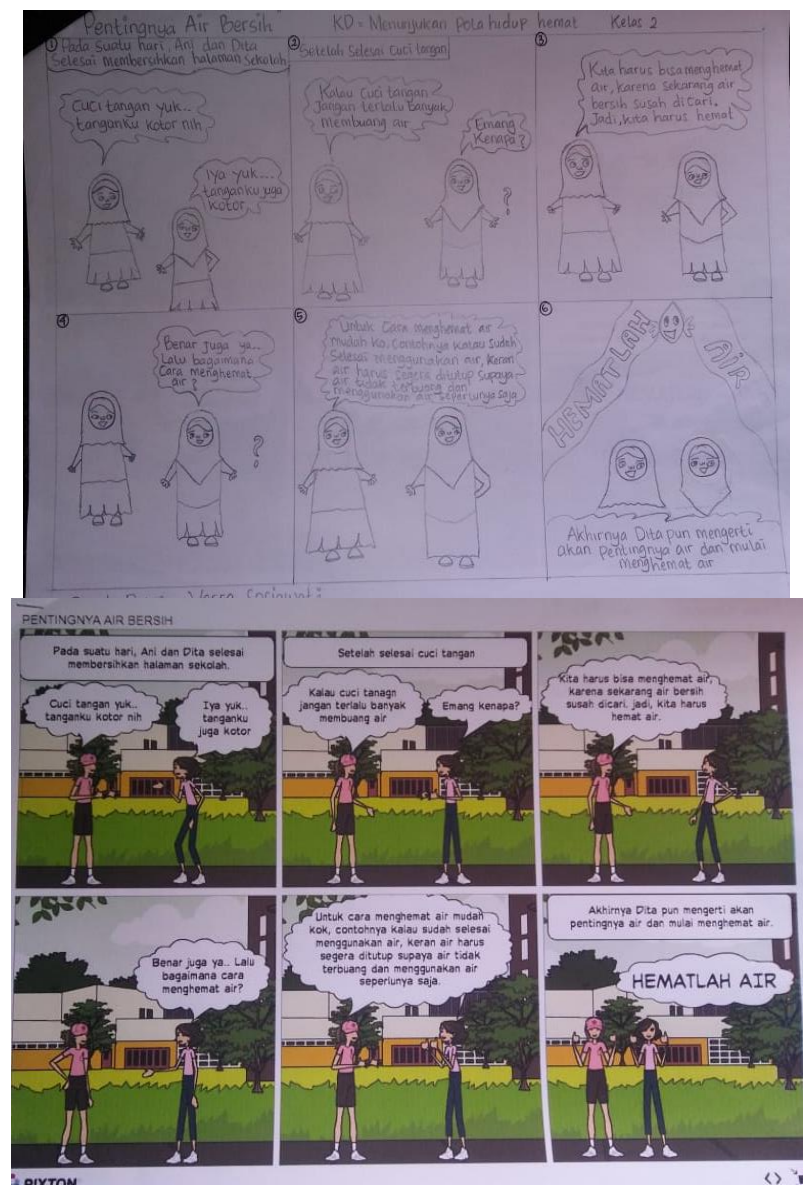

Gambar 3. Contoh Komik Strip yang dibuat melalui aplikasi pixton (kiri desain awal, kanan setelah menggunakan apliasi pixton) 
Suatu analisis terhadap bahasa komik oleh Thorndike (Nana Sudjana dan Ahmad Rivai, 2010: 67) menunjukkan bahwa anak yang membaca sebuah buku komik setiap bulan, hampir dua kali banyaknya kata-kata yang dapat dibaca sama dengan yang terdapat pada buku-buku bacaan yang dibacanya setiap tahun terus menerus. Dari analisis tersebut Thorndike mengambil kesimpulan bahwa baik jumlah maupun perwatakan dari segi perbendaharaan kata melengkapi secara praktis dalam membaca untuk para pembaca muda.

Peranan pokok media komik adalah kemampuan menciptakan minat peserta didik. Penggunaan komik dalam pembelajaran hendaknya dipadukan dengan metode mengajar yang tepat sehingga media komik akan dapat menjadi alat pengajaran yang efektif. Guru perlu mengarahkan para siswa untuk memilih komik sebagai bahan bacaan yang bukan hanya menyenangkan namun juga mengandung nilai edukatif yang baik sesuai dengan taraf berfikir peserta didik. Guru harus menolong peserta didik menuju cakrawala yang lebih luas akan minat serta apresiasinya. Buku-buku komik dapat dipergunakan secara efektif oleh guru-guru dalam usaha membangkitkan minat, mengembangkan perbendaharaan kata-kata dan keterampilan membaca, serta untuk memperluas minat baca. Sebagai media pembelajarn, komik memiliki peran utama untuk menarik anak-anak agar mau membaca materi tanpa harus diminta atau diperintah.

\section{Penguasaan Teknologi Untuk Mahasiswa Calon Guru Sekolah Dasar}

Kecepatan perkembangan ilmu pengetahuan dan teknologi menuntut perubahan cara dan strategi guru dalam mengajar. Guru tidak mungkin menjadi satu-satunya sumber belajar yang mampu menuangkan segala ilmu pengetahuan dan informasi bagi anak didik. Guru hendaknya membimbing siswa untuk menemukan data dan informasi sendiri serta mengolah dan mengembangkannya, oleh karena itu diperlukan adanya upaya untuk meningkatkan kualitas pembelajaran dengan mengubah peran guru sebagai pusat informasi (teacher centered) menjadi berperan sebagai fasilitator, mediator, dan teman yang memberikan kondisi yang kondusif untuk terjadinya konstruksi pengetahuan. Karena itu dalam proses pembelajaran perlu juga dikembangkan cara-cara mengajar yang baru pula, di antaranya ialah cara

Caruban: Jurnal Ilmiah Pendidikan Dasar 2(2), 71-83, Juli 2019

p-ISSN 2615-1391, e-ISSN 2620-3219 @Prodi PGSD Universitas Swadaya Gunung Jati 
mengajar dengan menggunakan komputer. Dengan bantuan komputer dapat diajarkan cara-cara mencari informasi baru, yaitu dengan menyeleksi dan mengolah pertanyaan, sehingga terdapat jawaban terhadap suatu pertanyaan itu.

Penerapan teknologi komputer mendorong proses pembelajaran ke arah "individual learning", di mana posisi guru bergeser dari instruktur tradisional ke arah mentor. Selain itu, pembelajaran individu mendorong siswa ke arah belajar aktif, kreatif dan interaktif. Dengan demikian maka perolehan pengetahuan siswa tidak lagi bersumber dari transfer ilmu oleh guru, melainkan melalui kegiatan membangun ilmu oleh siswa sendiri. Keunggulan penggunaan komputer dalam pembelajaran didukung karena kemampuan komputer untuk menyajikan informasi dalam bentuk multimedia (teks, gambar, audio, video, animasi, simulasi); komputer dapat diprogram untuk melakukan perhitungan, memeriksa hasil tes, dan memberikan umpan balik. Selain itu, teknologi internet memungkinkan bahan ajar dapat diakses kapan saja, dimana saja dan oleh siapa saja yang terhubung dengan internet.
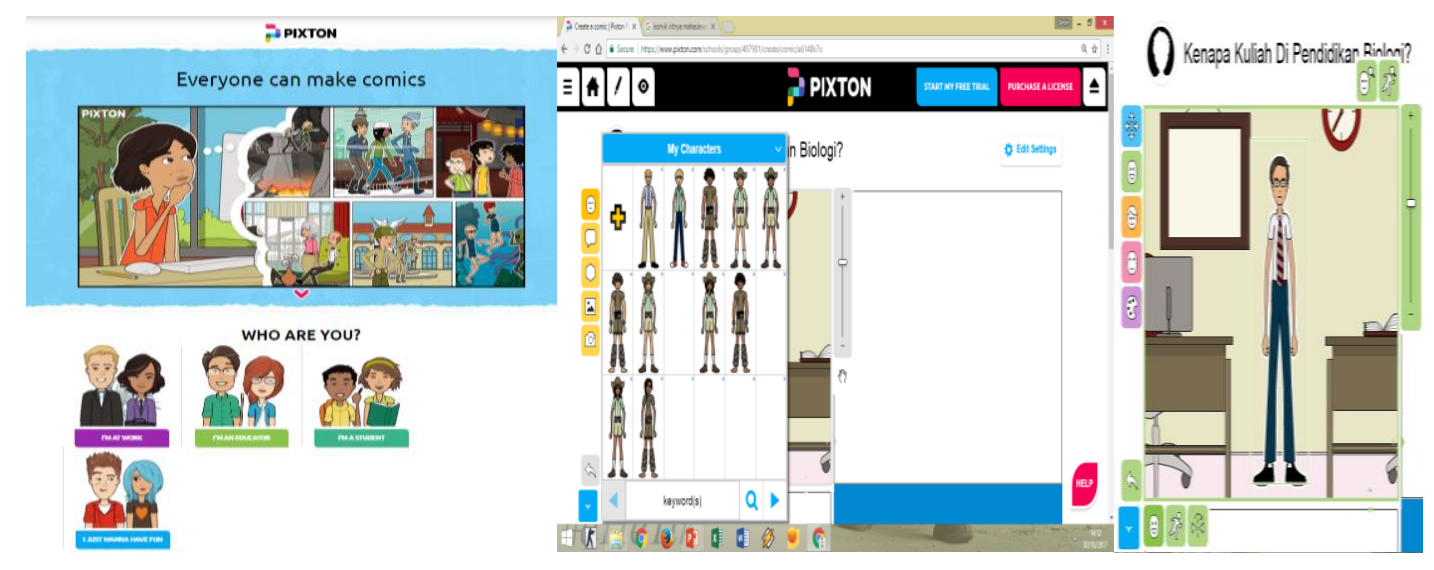

Gambar 4. Tampilan Aplikasi Pixton

Mengembangkan media pembelajaran berbantuan komputer pada dasarnya serupa halnya mengembangkan media pembelajaran non-komputer. Beberapa hal yang harus dipertimbangkan dalam proses pengembangan ini di antaranya 1) analisis dan seleksi fenomena, fakta atau informasi ilmu pengetahuan alam yang akan disajikan, 2) target kemampuan yang diharapkan 
dicapai siswa lewat interaksinya dengan fenomena atau fakta tersebut, 3) bagaimana kerangka urutan aktivitas mental yang akan dilakukan siswa untuk memaknai fakta, fenomena atau informasi yang tersaji. Adapun Salah satu bentuk teknologi yang dapat digunakan dalam pembelajaran adalah aplikasi pixton untuk membuat komik dengan bantuan jaringan internet.

\section{Hasil Validasi Pakar Terhadap Produk Komik Dengan Aplikasi Pixton}

Sebelum Produk komik dengan aplikasi pixton ini di implementasi kepada siswa sekolah dasar, maka terlebih dahulu produk ini di nilai oleh tiga pakar dalam bidang pendidikan dasar, media pembelajaran dan pendidikan nilai untuk memastikan kelayakan penggunaanya dalam kegiatan pembelaran siswa sekolah dasar. Tabel 2 merangkum hasil - hasil validasi ahli terhadap produk pengembangan komik pendidikan lingkungan hidup dengan aplikasi pixton untuk siswa sekolah dasar.

Table 2. Rekapitulasi Hasil Validasi Ahli Terhadap produk Pengembangan komik

Pendidikan Lingkungan Hidup dengan aplikasi pixton Untuk Siswa Sekolah Dasar

\begin{tabular}{lll}
\hline Aspek Penilaian & Indikator Penilaian & Hasil Penliaian \\
\hline Isi / Text & $\begin{array}{l}\text { Isi Text Singkat, } \\
\text { Padat akan } \\
\text { Informasi, jelas } \\
\text { Keterbacaannya }\end{array}$ & $\begin{array}{l}\text { Ketiga Validator menyatakan bahwa komik } \\
\text { yang dikembangkan oleh mahasiswa calon } \\
\text { guru SD dengan aplikasi pixton isi text } \\
\text { singkat, padat akan informasi dan jelas } \\
\text { keterbacaannya. }\end{array}$ \\
Desain & $\begin{array}{l}\text { Warna menarik, } \\
\text { ukuran penyusun } \\
\text { elemen proposional } \\
\text { pesan yang ingin } \\
\text { disampaikan } \\
\text { menjadi pusat } \\
\text { perhatian. }\end{array}$ & $\begin{array}{l}\text { Dua Validator menyatakan bahwa komik } \\
\text { yaru SD dengangan aplikasi pixton memiliki } \\
\text { warna yang menarik, ukuran penyusnan } \\
\text { elemen proposional dan pesan yang ingin } \\
\text { disampaikan bisa menjadi pusat perhatian }\end{array}$ \\
& $\begin{array}{l}\text { Gambar Menarik, } \\
\text { bermakna sebagai } \\
\text { penyampai pesan } \\
\text { dan orisinil }\end{array}$ & $\begin{array}{l}\text { Dua Validator menyatakan bahwa komik } \\
\text { yang dikembangkan oleh mahasiswa calon } \\
\text { guru SD dengan aplikasi pixton memiliki } \\
\text { gambar yang menarik dan bermakna } \\
\text { sebagai penyampai pesan mengenai }\end{array}$ \\
\hline
\end{tabular}

Caruban: Jurnal Ilmiah Pendidikan Dasar 2(2), 71-83, Juli 2019

p-ISSN 2615-1391, e-ISSN 2620-3219 @Prodi PGSD Universitas Swadaya Gunung Jati 
lingkungan hidup

Tujuan

Penyampain

Pesan

Pesan sangat mudah

Ketiga Validator menyatakan bahwa komik ditangkap pembaca yang dikembangkan oleh mahasiswa calon khsusnya siswa SD guru SD dengan aplikasi pixton pesannya dapat dengan sangat mudah ditangkap oleh pembaca khsusunya siswa SD

\section{Simpulan dan Rekomendasi}

Penelitian ini berupaya untuk mengembangkan metode perkuliahan yang dapat memberikan keteramipilan pembuatan bahan ajar digital dalam bentuk komik untuk mahasiswa calon guru sekolah dasar di salah satu perguruan tinggi swasta kota Cirebon. Hasil Penelitian menunjukan mahasiwa calon guru sekolah dasar mampu merancang dan membuat komik dengan aplikasi pixton dalam mengembangkan materi pembelajaran sekolah dasar untuk mata pelajaran pendidikan lingkungan hidup.

\section{Acknowledgment}

Penulis mengucapkan terima kasih kepada berbagai pihak yang telah membantu dalam penulisan makalah ini. Makalah ini didanai oleh Skema Riset Dosen Pemula (RDP) Universitas Swadaya Gunung Jati Cirebon tahun pendanaan 2019

\section{Daftar Pustaka}

Anderson, Lorin W. Et al.(2001).A Taxonomy for Learning, Teaching and Assessing, A Revison of Bloom's Taxonomy of Education Objectives. New York: Addison Wesley Logman. Inc.

Cary, Stephen. (2004). Going Graphic: Comics at Work in the Multilingual Classroom. Heinemann M.S. Gumelar. 2004. Comic Making. Jakarta: PT Indeks. 145

Hanafin, M.J. \& Peck K.L (1988). The Design, Development and evaluation instructional software. New York: Macmillan Publishing Company.

Kurniawan, D.T. (2013). Kreatifitas Mahasiswa Calon Guru matematika Melalui Model pembelajaran berbasis masalah (PjBL) pada matakuliah Program Komputer. Jurnal Logika Unswagati (IX) tahun VI.

Kurniawan, D.T. (2016). Profil literasi TIK (Teknologi Informasi dan Komunikasi) Mahasiswa Calon Guru Mateamtika di Salah satu Perguruan Tinggi Swasta Kota Cirebon. Proceeding Riksa Bahsa X "Literasi dan Budaya Bangsa". ISBN

Caruban: Jurnal Ilmiah Pendidikan Dasar 2(2), 71-83, Juli 2019

p-ISSN 2615-1391, e-ISSN 2620-3219 @Prodi PGSD Universitas Swadaya Gunung Jati 
978-602-60080-0-8 Program Studi Pendidkan Bahasa dan Sastra Indonesia SPs UPI.

Mayer, R. E. \& Sims, V. K. (1994) For Whom Is a Picture Worth a Thousand Words? Extensions of a Dual-Coding Theory of Multimedia Learning, Journal of Educational Psychology, 86 (3), 389-401

Maryanti, Sri. (2017). Profil Pemanfaatan Teknologi Informasi dan Komunikasi (TIK) Sebagai Media Pengembangan Bahan Ajar Digital Oleh Mahasiswa Calon Guru Biologi. Prosiding Seminar Nasional Pendidikan IPA IX UNY Karangmalang.

Sadiman, A. et.al. (2010). Media Pendidikan Pengertian, Pengembangan dan Pemanfaatannya. Jakarta: Rajawali Pers

Sudjana, R. (2009). Media pengajaran. Edisi Revisi. Bandung: Penerbit Sinar Baru Algensindo.

Slavin, R.E. (1992). Research Metohds In education. New jersey. Prentice Hall International Inc.

The Korea Times, available at: http://www.koreatimes.co.kr/www/news/art/2010/03/135_62659.html.

Yudhi Munadi. (2013). Media Pembelajaran (Sebuah Dokumen Baru). Jakarta: GP Press Group. 